\title{
Growth and photosynthetic pigment content in Salvia hispanica L. with macronutrient omission in nutrient solution
}

\section{Crescimento e índice de pigmentos fotossintéticos em Salvia hispanica L. com omissão de macronutrientes em solução nutritiva}

\section{Gilvanda Leão dos ANJOS'; Francielle Medeiros COSTA2; Celicleide Quaresma LOBO³; Aline dos Anjos SOUZA ${ }^{4}$; Girlene Santos de SOUZA ${ }^{5}$; Anacleto Ranulfo dos SANTOS ${ }^{6}$}

\begin{abstract}
${ }^{1}$ Autor para correspondência; Agrônoma, Mestranda do programa de Ciências Agrárias, Universidade Federal do Recôncavo da Bahia, gilvandas218s2@hotmail.com

${ }^{2}$ Agrônoma, Mestranda do programa Solos e Qualidade de Ecossistemas, Universidade Federal do Recôncavo da Bahia, fran-eng@hotmail.com

${ }^{3}$ Agrônoma, Universidade Federal do Recôncavo da Bahia, cleidequaresma@hotmail.com

${ }^{4}$ Agrônoma, Mestranda do programa Solos e Qualidade de Ecossistemas, Universidade Federal do Recôncavo da Bahia, eng.alinesouza@gmail.com

${ }^{5}$ Agrônoma, Dra., Professora Associada 1, Universidade Federal do Recôncavo da Bahia, Centro de Ciências Agrárias, Ambientais e Biológicas; Rua Rui Barbosa, 710, CEP: 44380-000, Cruz das Almas, Bahia; girlenessouza50@gmail.com

${ }^{6}$ Agrônomo, Dr., Professor Titular, Universidade Federal do Recôncavo da Bahia, anacleto@ufrb.edu.br
\end{abstract}

\section{Recebido em: 12-10-2017; Aceito em: 20-01-2018}

\begin{abstract}
Due to the importance of the chia crop, standing out among Lamiaceae for its medicinal use, there are few studies that report the nutritional disorders therein. The objective of this study was to evaluate the effect of macronutrient omission on the growth and photosynthetic pigment content of chia grown in nutrient solution. The study was carried out in a greenhouse at the Federal University of Recôncavo da Bahia-UFRB, in the municipality of Cruz das Almas, state of Bahia. The design was completely randomized, with five replicates and seven treatments: complete nutrient solution and macronutrient omissions. The nutrient solution used was that of Hogland \& Arnon (1950) modified. After 45 days of cultivation, the evaluations were performed. For the variables plant height, number of leaves, stem diameter, leaf mass ratio, and dry mass yield, treatment with $\mathrm{N}$ omission provided the lowest values compared to other treatments. With $\mathrm{P}$ omission, the leaf area presented lower value in relation to the others. For chlorophylls, Ca omission was responsible for providing the lowest values. Macronutrient omission affects the growth of chia plants in the decreasing order of $\mathrm{N}>\mathrm{P}>\mathrm{K}>\mathrm{Ca}>\mathrm{S}>\mathrm{Mg}$, and the photosynthetic pigment content in the decreasing order of $\mathrm{N}>\mathrm{Ca}>\mathrm{K}>\mathrm{Mg}>\mathrm{S}>\mathrm{P}$.
\end{abstract}

Additional keywords: chia; mineral nutrition; missing element.

\begin{abstract}
Resumo
Devido à importância da cultura da chia, destacando-se dentre as lamiaceaes pelo seu uso medicinal, poucas são as pesquisas que relatam as desordens nutricionais na mesma. Objetivou-se avaliar o efeito da omissão dos macronutrientes no crescimento e no índice de pigmentos fotossintéticos de chia, cultivada em solução nutritiva. O estudo foi realizado em casa de vegetação, no Câmpus da Universidade Federal do Recôncavo da BahiaUFRB, no município de Cruz das Almas-BA. O delineamento utilizado foi o inteiramente casualizado, com cinco repetições, e sete tratamentos: solução nutritiva completa e omissões de macronutrientes. A solução nutritiva utilizada foi a de Hogland \& Arnon (1950) modificada. Após 45 dias de cultivo, realizaram-se as avaliações. Para as variáveis altura das plantas, número de folhas, diâmetro do caule, razão de massa foliar e rendimento de massa seca, o tratamento com omissão de $\mathrm{N}$ proporcionou os menores valores, comparada com os demais tratamentos. Com a omissão de $\mathrm{P}$, a área foliar apresentou menor valor em relação aos demais. Já para as clorofilas, a omissão de Ca foi responsável por proporcionar os menores valores. A omissão de macronutrientes afeta o crescimento das plantas de chia na ordem decrescente de $\mathrm{N}>\mathrm{P}>\mathrm{K}>\mathrm{Ca}>\mathrm{S}>\mathrm{Mg}$, e para os índices de pigmentos fotossintéticos, na ordem decrescente de $\mathrm{N}>\mathrm{Ca}>\mathrm{K}>\mathrm{Mg}>\mathrm{S}>\mathrm{P}$.
\end{abstract}

Palavras-chave adicionais: chia; elemento faltante; nutrição mineral.

\section{Introduction}

The plant Salvia hispanica L., commonly known as chia, belonging to the family Lamiaceae, is an annual herbaceous plant (Cahill, 2003), whose group includes plants that are often denominated as medicinal, aromatic, and condimentary, such as mint, basil, oregano, and thyme. This plant originates from the mountainous areas of western and central Mexico and Guatemala (Orozco \& Romero, 2003). 
Its seeds have been highlighted as food because they are rich in dietary fiber, antioxidants, proteins, and a-linolenic fatty acids, with innumerable benefits to human health (Sandoval-Oliveros \& Paredes-López, 2013).

On the other hand, agronomic information is still scarce, especially regarding its mineral nutrition, as for example the nutrient omission, since the majority of studies are directed to the seeds, relating their composition and functional properties.

Macronutrients play a key role in plant growth and development. Each macronutrient has its own character and, therefore, is involved in different metabolic processes of the vegetable, and its application results in crop yield, growth, and quality. Several studies have been carried out to investigate the aspects of this group of nutrients, since they are involved in every stage of the plant cycle (Tripathi et al., 2014), therefore, in the absence of one of the macros, there will be an impairment to the plant cycle.

Due to the great heterogeneity and complexity that the soil presents, the technique of plant cultivation in nutrient solution brings innumerable advances in the knowledge about plant nutrition, given the greater control of the solution composition (Gondim et al., 2016). Studies with plants in a controlled environment suggest that the effects of these environments on plant growth are easier to study than the effects under field conditions (Marschner, 2012).

Among these advances, the missing induction or missing element technique is considered as a classic study in the area of mineral nutrition of plants (Prado, 2008).
The objective of this study was to evaluate the effect of macronutrient omission on the growth and photosynthetic pigment content of chia grown in nutrient solution.

\section{Material and methods}

The present study was carried out from April to June 2017 at the Experimental Station of the Center for Agrarian, Environmental and Biological Sciences of the Federal University of Recôncavo da Bahia, in the municipality of Cruz das Almas-BA, in a protected environment.

The experiment was completely randomized, with seven treatments: Complete Nutrition Solution; Nitrogen Omission (-N); Phosphorus Omission (-P); Potassium Omission (-K); Calcium Omission (-Ca); Magnesium Omission (-Mg); Sulfur Omission (-S), with five replicates. Each experimental plot was composed of one plant.

The chia seeds used were purchased in the local commerce, in an establishment selling natural products. They were sown in plastic trays containing washed sand. The seedlings with about $8 \mathrm{~cm}$ height were transferred to $3 \mathrm{dm}^{3}$ plastic pots, containing substrate consisting of washed sand and vermiculite, in the ratio of 3:1, respectively. The nutrient solution used was that of Hogland \& Arnon (1950) modified (Table $1)$, containing the following nutrient concentrations, in $\mathrm{mg} \mathrm{L}^{-1}: 210.0 \mathrm{~N} ; 31.0 \mathrm{P} ; 234.0 \mathrm{~K} ; 200.0 \mathrm{Ca} ; 48.0 \mathrm{Mg}$; $64.0 \mathrm{~S}$.

Table 1 - Volume $(\mathrm{mL})$ of stock solutions to prepare one liter of nutrient solution proposed by Hoagland \& Arnon (1950) used in the experiment.

\begin{tabular}{lccccccc}
\hline Stock solution $(1 \mathrm{M})$ & $\begin{array}{c}\text { Complete } \\
\text { solution }\end{array}$ & $-\mathrm{N}$ & $-\mathrm{P}$ & $-\mathrm{K}$ & $-\mathrm{Ca}$ & $-\mathrm{Mg}$ & $-\mathrm{S}$ \\
\hline $\mathrm{KH}_{2} \mathrm{PO}_{4}$ & 1 & 1 & - & - & 1 & 1 & 1 \\
$\mathrm{KNO}_{3}$ & 5 & - & 5 & - & 5 & 3 & 3 \\
$\mathrm{Ca}\left(\mathrm{NO}_{3}\right)_{2}$ & 5 & - & 5 & 5 & - & 4 & 4 \\
$\mathrm{MgSO}$ & 2 & 2 & 2 & 2 & 2 & - & - \\
$\mathrm{KCl}$ & - & 5 & 1 & - & - & 2 & 2 \\
$\mathrm{CaCl}$ & - & 5 & - & - & - & 1 & 1 \\
$\mathrm{NH}_{4} \mathrm{H}_{2} \mathrm{PO}_{4}$ & - & - & - & 1 & - & - & - \\
$\mathrm{NH}_{4} \mathrm{NO}_{3}$ & - & - & - & 2 & 5 & - & - \\
$\left(\mathrm{NH}_{4}\right)_{2} \mathrm{SO}_{4}$ & - & - & - & - & - & 2 & - \\
$\mathrm{MgNO}_{3}$ & - & - & - & - & - & - & 2 \\
Iron-EDTA & 1 & 1 & 1 & 1 & 1 & 1 & 1 \\
Micronutrients & 1 & 1 & 1 & 1 & 1 & 1 & 1
\end{tabular}

*Iron-EDTA: $26.1 \mathrm{~g}$ of disodium-EDTA in $286 \mathrm{~mL}$ of $\mathrm{NaOH} 1 \mathrm{~N}+24.9 \mathrm{~g} \mathrm{FeSO} 4.7 \mathrm{H}_{2} \mathrm{O}$. This solution is aerated by one night.

${ }^{* *}$ Micronutrients solution $\left(\mathrm{g} \mathrm{L}^{-1}\right): \mathrm{H}_{3} \mathrm{BO}_{3}=2.86 ; \mathrm{MnCl}_{2} 4 \mathrm{H}_{2} \mathrm{O}=1.81 ; \mathrm{ZnCl}_{2}=0.10 ; \mathrm{CuCl}_{2}=0.04 ; \mathrm{H}_{2} \mathrm{MoO}_{4} \mathrm{H}_{2} \mathrm{O}=0.02$.

The nutrient solutions were applied weekly after seedling transplantation with a volume of $200 \mathrm{~mL}$, totaling five applications.

The experiment was terminated at 45 days of cultivation due to the marked responses to the treatments, and the following variables were evaluated: plant height, stem diameter, number of leaves, root volume, root dry mass, leaf dry mass, stem dry mass, shoot dry mass, total dry mass, leaf area, leaf area ratio, specific leaf area, leaf mass ratio, chlorophyll $A$, $\mathrm{B}$, and total chlorophyll, and chlorophyll A/B ratio.

Plant height was measured with a ruler from the neck to the apex of the plant (terminal bud); stem diameter was considered at $1 \mathrm{~cm}$ from the substrate, 
with the aid of a $0.01-\mathrm{mm}$ digital caliper; the number of leaves was counted manually; and root volume was obtained with the aid of a graduated cylinder. Chlorophyll indexes $A$ and $B$ were collected with an electronic meter (Falker, model CFL1030). The total leaf area per plant was determined using the leaf dry mass ratio and the dry mass of 10 leaf discs, collected from the base to the apex of the plant, with the aid of a known area perforator, avoiding the central vein, as described by Benincasa (2003).

The plants were sectioned into leaves, stems, and roots and dried in an oven with forced air circulation at $60 \pm 2 \stackrel{\circ}{\mathrm{C}}$ until constant mass, from which the dry mass of shoots and roots were determined using an analytical balance with precision of $10^{-3}$. The leaf area ratio, leaf mass ratio, and specific leaf area were determined from the values of total leaf area, expressed in $\mathrm{cm}^{2}$, and total dry mass, expressed according to Benincasa (2003).

The data were analyzed with the aid of the statistical software program "R" (R Development Core Team, 2017). Normality was verified using the ShapiroWilk test and, according to the level of significance, the Scott-Knott test was applied at a $5 \%$ error probability to group means.

\section{Results and discussion}

There was a significant effect $(p<0.05)$ of macronutrient omission for most of the analyzed variables, except for root volume, specific leaf area, leaf area ratio, and chlorophyll $A / B$ ratio.

The effects on growth variables and the photosynthetic pigment contents will be discussed for each element separately and compared to the complete nutrient solution when statistically different.

\section{Nitrogen Omission}

Regarding height, the chia plants submitted to treatment with the absence of $\mathrm{N}$ in the nutrient solution grew approximately $19 \%$ less when compared to the treatment with complete solution, evidencing the importance of $\mathrm{N}$ in plant growth. This same behavior was observed for the variable stem diameter, with a reduction of approximately $56 \%$ (Table 2 ). Silva Junior et al. (2011), in a study with macronutrient omission in Arrabidaea chica (H. \& B.) Verlot, observed that $\mathrm{N}$ was the only nutrient that limited growth in stem diameter, with a reduction of $24 \%$ in relation to the complete treatment. Regarding the number of leaves, $\mathrm{N}$ omission reduced it by $91 \%$ in relation to the plants grown in complete solution.

Table 2 - Height, stem diameter and number of leaves of chia plants grown in nutrient solution with omission of macronutrients.

\begin{tabular}{lccc}
\hline Treatments & $\begin{array}{c}\text { Height } \\
(\mathrm{cm})\end{array}$ & $\begin{array}{c}\text { Stem diameter } \\
(\mathrm{mm})\end{array}$ & $\begin{array}{c}\text { Number of leaves } \\
\text { (leaves per plant) }\end{array}$ \\
\hline Complete solution & $45.80 \mathrm{a}$ & $5.09 \mathrm{a}$ & $65.80 \mathrm{~b}$ \\
N omission & $37.30 \mathrm{~b}$ & $2.27 \mathrm{C}$ & $6.20 \mathrm{C}$ \\
P omission & $51.10 \mathrm{a}$ & $4.26 \mathrm{~b}$ & $57.40 \mathrm{~b}$ \\
K omission & $48.20 \mathrm{a}$ & $4.78 \mathrm{~b}$ & $70.20 \mathrm{a}$ \\
Ca omission & $42.60 \mathrm{~b}$ & $5.54 \mathrm{a}$ & $74.00 \mathrm{a}$ \\
Mg omission & $51.80 \mathrm{a}$ & $5.90 \mathrm{a}$ & $65.60 \mathrm{~b}$ \\
S omission & $46.40 \mathrm{a}$ & $5.38 \mathrm{a}$ & $62.60 \mathrm{~b}$ \\
\hline CV $(\%)$ & 9.98 & 12.86 & 12.42
\end{tabular}

* Means followed by distinct letters in the column differ from each other by the Scott-Knott test $(p<0.05)$.

Growth reduction is one of the main effects caused by $\mathrm{N}$ deficiency in plants (Taiz \& Zeiger, 2010). Nitrogen is one of the elements most required by plants, as it is a constituent of amino acids, amides, proteins, nucleic acids, nucleotides, and coenzymes, so that its deficiency rapidly inhibits plant growth (Souza \& Fernandes, 2006). According to Marschner (2012), in this type of deficiency, growth reduction is explained in part by the low absorption of nutrients.

Consequently, there was suppression in the dry matter production, being influenced by the treatment with absence of $\mathrm{N}$, where the reductions were approximately 99\% (leaves), 87\% (stem), 94\% (root), $94 \%$ (shoot), and $94 \%$ (total), compared to the treatment in which a complete nutrient solution was delivered (Table 3).

The leaf mass ratio is the ratio between leaf dry mass and total plant mass, that is, the total phytomass fraction in the form of leaves (Evans, 1972). These lower values found for this variable indicate a lower percentage (reduction of $99.86 \%$ ) of assimilatory tissue in total phytomass (Table 4).

Since the plants in this treatment did not have enough leaves, it was impossible to collect data for the variables leaf area and photosynthetic pigment content (chlorophyll A, B, and total chlorophyll).

\section{Phosphorus Omission}

$\mathrm{P}$ omission reduced the growth of chia plants, affecting the studied variables, except plant height, number of leaves, stem and root dry mass, leaf mass ratio, and photosynthetic pigment content, represented by chlorophyll $A, B$, and total chlorophyll, that is, for these variables there was no difference for the plants grown in complete solution. The reduction in growth in plants grown in the absence of $P$ is common in many 
species, having as explanation the reduction of cell division (Silva Junior et al., 2011).

For the variable stem diameter, there was a decrease of approximately $17 \%$ when compared to treatment with complete solution (Table 2).

Regarding the dry mass of chia plants, when compared to the nutrient solution containing all the nutrients, it was observed that there was a decrease in leaf dry mass, shoot dry mass, and total dry mass, being these values of $31 \%, 22 \%$, and $24 \%$, respec- tively (Table 3). The same was described by Silva Junior et al. (2011), who obtained the lowest yields of shoot dry mass in pariri (Arrabidaea chica) in the treatment with $\mathrm{P}$ omission.

Among all variables, leaf area was the one that presented the largest reduction (approximately $38 \%$ ) when compared to the treatment with complete solution. For leaf mass ratio, the observed reduction was approximately $8 \%$ (Table 4 ).

Table 3 - Leaf dry mass (LDM), stem dry mass (SDM), aerial part dry mass (APDM), root dry mass (RDM) and total dry mass (TDM) of the chia plants grown in nutrient solution with omission of macronutrients.

\begin{tabular}{lccccc}
\hline Treatments & LDM $(\mathrm{g})$ & SDM $(\mathrm{g})$ & APDM $(\mathrm{g})$ & RDM $(\mathrm{g})$ & TDM $(\mathrm{g})$ \\
\hline Complete solution & $3.03 \mathrm{~b}$ & $2.30 \mathrm{~b}$ & $5.34 \mathrm{~b}$ & $2.57 \mathrm{a}$ & $7.91 \mathrm{a}$ \\
N omission & $0.03 \mathrm{e}$ & $0.30 \mathrm{c}$ & $0.33 \mathrm{e}$ & $0.16 \mathrm{~b}$ & $0.49 \mathrm{~d}$ \\
P omission & $2.11 \mathrm{~d}$ & $2.08 \mathrm{~b}$ & $4.20 \mathrm{~d}$ & $1.83 \mathrm{a}$ & $6.03 \mathrm{c}$ \\
K omission & $2.92 \mathrm{~b}$ & $2.19 \mathrm{~b}$ & $5.12 \mathrm{c}$ & $2.02 \mathrm{a}$ & $7.15 \mathrm{~b}$ \\
Ca omission & $2.54 \mathrm{c}$ & $2.40 \mathrm{a}$ & $4.94 \mathrm{c}$ & $2.07 \mathrm{a}$ & $7.02 \mathrm{~b}$ \\
Mg omission & $3.54 \mathrm{a}$ & $2.55 \mathrm{a}$ & $6.09 \mathrm{a}$ & $2.18 \mathrm{a}$ & $8.27 \mathrm{a}$ \\
S omission & $3.18 \mathrm{~b}$ & $2.45 \mathrm{a}$ & $5.63 \mathrm{~b}$ & $2.23 \mathrm{a}$ & $7.87 \mathrm{a}$ \\
\hline CV $(\%)$ & 10.35 & 11.07 & 7.61 & 33.33 & 11.63 \\
\hline
\end{tabular}

* Means followed by distinct letters in the column differ from each other by the Scott-Knott test $(p<0.05)$.

Table 4 - Leaf area (LA), leaf mass ratio (LMR), chlorophyll a (Chlor a), chlorophyll b (Chlor b), and total chlorophyll of chia plants grown in nutrient solution with omission of macronutrients.

\begin{tabular}{lccccc}
\hline Treatments & $\begin{array}{c}\text { LA } \\
\left(\mathrm{cm}^{2} \text { per plant) }\right.\end{array}$ & $\begin{array}{c}\text { LMR } \\
\left(\mathrm{g} \mathrm{g}^{-1}\right)\end{array}$ & Chlor a & Chlor b & $\begin{array}{c}\text { Total } \\
\text { chlorophyll }\end{array}$ \\
\hline Complete solution & $1077.34 \mathrm{a}$ & $0.38 \mathrm{~b}$ & $30.70 \mathrm{a}$ & $10.22 \mathrm{a}$ & $40.93 \mathrm{a}$ \\
N omission & - & $0.05 \mathrm{c}$ & - & - & - \\
P omission & $670.12 \mathrm{~b}$ & $0.35 \mathrm{~b}$ & $31.32 \mathrm{a}$ & $10.22 \mathrm{a}$ & $41.55 \mathrm{a}$ \\
K omission & $939.05 \mathrm{~b}$ & $0.41 \mathrm{a}$ & $27.62 \mathrm{~b}$ & $8.26 \mathrm{~b}$ & $35.88 \mathrm{~b}$ \\
Ca omission & $1178.73 \mathrm{a}$ & $0.36 \mathrm{~b}$ & $25.22 \mathrm{c}$ & $7.12 \mathrm{~b}$ & $32.34 \mathrm{c}$ \\
Mg omission & $1333.65 \mathrm{a}$ & $0.42 \mathrm{a}$ & $28.44 \mathrm{~b}$ & $8.60 \mathrm{~b}$ & $37.04 \mathrm{~b}$ \\
S omission & $1175.41 \mathrm{a}$ & $0.40 \mathrm{a}$ & $29.96 \mathrm{a}$ & $9.10 \mathrm{a}$ & $39.06 \mathrm{a}$ \\
\hline CV $(\%)$ & 19.58 & 12.28 & 6.90 & 11.24 & 7.66 \\
\hline
\end{tabular}

* Means followed by distinct letters in the column differ from each other by the Scott-Knott test $(p<0.05)$.

\section{Potassium Omission}

There was a reduction in growth variables and in the photosynthetic pigment contents of chia plants when submitted to omission of the macronutrient $\mathrm{K}$. Only for the variables plant height, leaf and root dry mass, there were no differences in relation to the complete solution. The results corroborate in part those of Vieira et al. (2011), who observed that the omission of $\mathrm{K}$ to moringa plants did not cause difference in the dry mass of roots, stems, and leaves when compared to the treatment with complete solution.

Stem diameter decreased about $6 \%$ when compared to the plants grown with complete solution (Table 2). Dry matter production was also influenced by this treatment, with reductions of $4 \%$ and $10 \%$ for the variables shoot dry mass and total dry mass, respectively (Table 3 ). For leaf area, this decrease was approximately $13 \%$ when compared to the treatment with complete solution (Table 4).

The photosynthetic pigments were influenced by the treatment in question. When compared with the complete solution, the values of chlorophyll $A, B$, and total chlorophyll had reductions of $10 \%, 19 \%$, and $13 \%$, respectively.

The effect of $\mathrm{K}$ on the limitation of plant growth is justified by its role in protein synthesis, sugar translocation, membrane permeability, in addition to the activity of several enzymes involved in respiration and photosynthesis, whose processes are required for the opening and closing of stomata (Silva et al., 2015).

\section{Calcium Omission}

The omission of $\mathrm{Ca}$ to chia reduced the analyzed variables, except stem diameter, root dry mass, leaf area, and leaf mass ratio, which did not differ from the treatment with complete solution.

For plant height, the observed reduction was $7 \%$ when compared to the treatment with complete solution (Table 2). Ca maintains the structural integrity of the membranes and cell walls, also acting as a 
regulator of several physiological and metabolic processes. With the omission of this macronutrient, the main effect is the reduction of the growth of apical meristematic tissues (Daflon et al., 2014).

For dry matter production, the observed reductions for leaves, shoots, and total dry mass were respectively $16 \%, 7.5 \%$, and $12 \%$ (Table 3 ). Vieira et al. (2011), evaluating $\mathrm{Ca}$ omission in nutrient solution for moringa plants, observed that regarding total dry mass, there were no significant changes in plant growth in relation to the complete treatment.

The reductions of photosynthetic pigment contents in the treatment with $\mathrm{Ca}$ omission, compared to the nutrient solution, were of $18 \%, 31 \%$, and $21 \%$, for chlorophyll A, B, and total chlorophyll, respectively (Table 4).

\section{Magnesium Omission}

The omission of this macronutrient only influenced the photosynthetic pigment contents, with observed reductions of $7.30 \%$ (chlorophyll A), $16 \%$ (chlorophyll B), and 9.50\% (total chlorophyll) (Table 4). This result can be justified by the fact that $\mathrm{Mg}$ is extremely important for chlorophyll, since it is part of its composition, being also an enzyme activator, and acting as a P carrier inside the plant (Malavolta, 2006).

Different results were found by Sorreano et al. (2011), who studied the omission of macronutrients in Croton urucurana Baill seedlings, observing that $\mathrm{Mg}$ was one of the nutrients that most negatively influenced the development of the species.

\section{Sulfur Omission}

The treatment with $\mathrm{S}$ omission did not differ from the complete solution for plant height, stem diameter, number of leaves, dry mass of leaves, shoots, and roots, total dry mass, leaf area, and photosynthetic pigment contents (chlorophyll A, B, and total). Exception occurred for the variables stem dry mass and leaf mass ratio, where the omission of this element increased these values about $5.2 \%$ and $6.5 \%$, respectively (Table 3 and 4 ).

Much of the $S$ that is metabolized by plants is destined to make essential amino acids, such as cystine, cysteine, and methionine, which in turn will form proteins. This explains why it is a structural element for plants (Gigolashvili \& Kopriva, 2014).

These observed results can be attributed to the fact that the iron-EDTA solution contains iron sulphate $\left(\mathrm{FeSO}_{4} .7 \mathrm{H}_{2} \mathrm{O}\right)$; it is assumed that this quantity is sufficient for the growth of chia plants.

\section{Conclusions}

Macronutrient omission affects the growth of chia plants in the decreasing order of $\mathrm{N}>\mathrm{P}>\mathrm{K}>\mathrm{Ca}>\mathrm{S}>\mathrm{Mg}$, and the photosynthetic pigment content in the decreasing order of $\mathrm{N}>\mathrm{Ca}>\mathrm{K}>\mathrm{Mg}>\mathrm{S}>\mathrm{P}$.

\section{References}

Benincasa MMP (2003) Análise de crescimento de plantas: noções básicas. UNESP. 41p.

Cahill JP (2003) Ethnobotany of Chia, Salvia hispanica L. (Lamiaceae). Economic Botany 57(4):604-618.

Daflon DSG, Freitas MSM, Carvalho AJC; Monnerat PH, Prins CL (2014) Sintomas visuais de deficiência de macronutrientes e boro em coentro. Horticultura Brasileira 32(1): 28-34.

Evans GC (1972) The quantitative analysis of plant growth. University of California Press. 734p.

Gigolashvili T, Kopriva S (2014) Transporters in plant sulfur metabolism. Frontiers in plant Science, 5:1-16.

Gondim ARDO, Prado RDM, Fonseca IM, Alves AU (2016) Crescimento inicial do milho cultivar brs 1030 sob omissão de nutrientes em solução nutritiva. Revista Ceres 63(5):706-714.

Hoagland DR, Arnon DI (1950). The water culture method for growing plants without soils. California Agricultural Experiment Station. 347p.

Malavolta E (2006) Manual de nutrição mineral de plantas. Ceres. $638 \mathrm{p}$.

Marschner H (2012) Mineral nutrition of higher plants. Elsevier. 643p.

Orozco B, Romero MR (2003) La chía, alimento milenario. Industria alimentaria 25(5):20-29.

Prado RM (2008) Nutrição de plantas. São Paulo: Unesp. 407p.

R Development Core Team (2017) - R: a language and environment for statistical computing.

Disponível em < http://www.r-project.org/> Acesso em 05 set. 2017

Sandoval-Oliveros MR, Paredes-López O (2013) Isolation and Characterization of Proteins from Chia Seeds (Salvia hispanica L.). Jounal of Agricultural and Food Chemistry 61(1):193-201.

Silva DAS, Viegas IJM, Okumura RS, Silva Junior ML, Viegas SFSS, Freitas JMN, Conceição HEO, Oliveira Neto CF (2015) Use of multidimensional scaling for analysis of teak plants (Tectona grandis) under omission of macronutrients. Australian Journal of Crop Science 9(5):355-362.

Silva Junior ML, Silva DAS, Melo VS, Santos MMLS, Santos PCT (2011) Crescimento, composição mineral e sintomas de deficiências de pariri cultivado sob omissão de macronutrientes. Revista de Ciências Agrárias 48(1):85-98. 
Sorreano MCM, Malavolta E, Silva DH, Cabral CP, Rodrigues RR (2011) Deficiency of macronutrients in sangra d'água (Croton urucurana, Baill.) seedlings. Cerne 7(3): 347-352.

Souza SR, Fernandes MS (2006) Absorção de Nutrientes. In: Fernandes MS, Nutrição Mineral de Plantas, Sociedade Brasileira de Ciência do Solo. p. 115-152

Taiz L, Zeiger E (2010) Plant physiology Sunderland. Sinauer Associates. 782 p.
Tripathi DK, Singh VP, Chauhan DK, Prasad SM, Dubey NK (2014) Role of macronutrients in plant growth and acclimation: recent advances and future prospective. In Improvement of Crops in the Era of Climatic Changes. Springer. p. 197-216.

Vieira H, Chaves LHG, Viégas RA (2011) Produção de matéria seca por mudas de moringa sob omissão de macronutrientes. Revista de Ciências Agrárias 50(1):189-195. 